\title{
Ablation of Cellular Prion Protein Does Not Ameliorate Abnormal Neural Network Activity or Cognitive Dysfunction in the J20 Line of Human Amyloid Precursor Protein Transgenic Mice
}

\author{
Moustapha Cissé, ${ }^{1,2}$ Pascal E. Sanchez, ${ }^{1,2}$ Daniel H. Kim, ${ }^{1}$ Kaitlyn Ho, ${ }^{1}$ Gui-Qiu Yu, ${ }^{1}$ and Lennart Mucke ${ }^{1,2}$ \\ ${ }^{1}$ Gladstone Institute of Neurological Disease and ${ }^{2}$ Department of Neurology, University of California, San Francisco, San Francisco, California 94158
}

Previous studies suggested that the cellular prion protein $\left(\operatorname{PrP}^{c}\right)$ plays a critical role in the pathogenesis of Alzheimer's disease (AD). Specifically, amyloid- $\beta(\mathrm{A} \beta)$ oligomers were proposed to cause synaptic and cognitive dysfunction by binding to $\operatorname{PrP}^{\mathrm{c}}$. To test this hypothesis, we crossed human amyloid precursor protein (hAPP) transgenic mice from line J20 onto a PrP ${ }^{c}$-deficient background. Ablation of $\operatorname{PrP}^{\mathrm{c}}$ did not prevent the premature mortality and abnormal neural network activity typically seen in hAPPJ20 mice. Furthermore, hAPPJ20 mice with or without $\operatorname{PrP}^{c}$ expression showed comparably robust abnormalities in learning and memory and in other behavioral domains at $6-8$ months of age. Notably, these abnormalities are not refractory to therapeutic manipulations in general: they can be effectively prevented by interventions that prevent $\mathrm{A} \beta$-dependent neuronal dysfunction also in other lines of hAPP transgenic mice. Thus, at least in this model, $\operatorname{PrP}^{\mathrm{c}}$ is not an important mediator of $\mathrm{A} \beta$-induced neurological impairments.

\section{Introduction}

Alzheimer's disease (AD) affects many millions of people and is on the rise worldwide (Thies and Bleiler, 2011). Amyloid- $\beta$ (A $\beta$ ) peptides, released from the amyloid precursor protein (APP), are implicated in its pathogenesis. At high concentrations, $\mathrm{A} \beta$ peptides form diverse assemblies, among which $\mathrm{A} \beta$ oligomers may be the most pathogenic (Cheng et al., 2007; Shankar et al., 2008; Ashe and Zahs, 2010; Sakono and Zako, 2010). One of the most important unresolved questions is whether $A \beta$ oligomers impair neuronal functions by interacting with specific cell surface receptors. $\mathrm{A} \beta$ oligomers bind a variety of receptors, including the receptor for advanced glycation end products (RAGE) (Origlia et al., 2009), $\alpha$-7-nicotinic acetylcholine receptor (Dineley et al., 2002), cellular prion protein $\left(\operatorname{PrP}^{\mathrm{c}}\right.$ ) (Laurén et al., 2009; Balducci et al., 2010), and Ephrin-type B2 receptor (EphB2) (Renner et al., 2010; Cissé et al., 2011). Determining which interaction most affects cognitive functions is an important objective.

$\mathrm{PrP}^{\mathrm{c}}$ has been reported to mediate $\mathrm{A} \beta$-induced deficits in hippocampal synaptic plasticity and cognitive impairments (Laurén et al., 2009; Gimbel et al., 2010). This membrane-anchored glycopro-

\footnotetext{
Received March 22, 2011; revised May 11, 2011; accepted June 4, 2011.

Author contributions: M.C., P.E.S., G.-Q.Y., and L.M. designed research; M.C.,P.E.S., D.H.K., G.-Q.Y., and K.H. performed research;M.C., P.E.S., and L.M. analyzed data; M.C., P.E.S., and L.M. wrote the paper.

The study was supported by NIH Grants NS065780, AG011385, and AG022074 to L.M. and National Center for Research Resources Grant RR18928 to the Gladstone Institutes. We thank Dr. E. Koo for the CT15 antibody, Dr. J. Palop for helpful comments, X. Wang for technical support, and G. Howard for editorial review; J. Carroll and Teresa Roberts for preparation of graphics; and M. Dela Cruz for administrative assistance. Behavioral data were obtained with the help of the Gladstone Institutes' Behavioral Core.

Correspondence should be addressed to Dr. Lennart Mucke, Gladstone Institute of Neurological Disease, 1650 Owens Street, San Francisco, CA 94158. E-mail: Imucke@gladstone.ucsf.edu.

DOI:10.1523/JNEUROSCI.1459-11.2011

Copyright $\odot 2011$ the authors $\quad 0270-6474 / 11 / 3110427-05 \$ 15.00 / 0$
}

tein helps to maintain the brain's white matter and regulate its innate immune cells, responses to oxidative stress, and neurogenesis (Aguzzi et al., 2008). $\operatorname{PrP}^{c}$ ablation prevented deficits in long-term potentiation (LTP) elicited by A $\beta$ oligomers in acute hippocampal slices (Laurén et al., 2009) and behavioral impairments in APPswe/ PSen $\Delta$ E9 transgenic mice (Gimbel et al., 2010). However, others could not reproduce the electrophysiological rescue (Calella et al., 2010; Kessels et al., 2010), and one study reported that acute intracerebroventricular injection of synthetic $\mathrm{A} \beta$ oligomers caused similar deficits in learning and memory in mice with or without $\operatorname{PrP}^{c}$ expression (Balducci et al., 2010).

Because the experimental design used in the latter study differs from the chronic exposure to $A \beta$ oligomers that neurons experience in human APP (hAPP) transgenic mice and in AD, we set out to replicate the reported rescue of behavioral functions (Gimbel et al., 2010) in hAPPJ20 mice. hAPPJ20 mice have a robust phenotype with a range of $\mathrm{AD}$-like alterations, including deficits in spatial and nonspatial learning and memory, behavioral abnormalities, synaptic impairments, changes in various synaptic activity-related proteins, amyloid plaques, dystrophic neurites, aberrant sprouting of axon terminals, astrocytosis, and microgliosis (Mucke et al., 2000; Cheng et al., 2007; Palop et al., 2007; Roberson et al., 2007, 2011; Meilandt et al., 2008; Harris et al., 2010; Cissé et al., 2011). We crossed hAPPJ20 mice onto a $\mathrm{PrP}^{\mathrm{c}}$-deficient background (Büeler et al., 1992) and compared hAPPJ20 mice with or without $\mathrm{PrP}^{\mathrm{c}}$ expression at 6-8 months of age in a battery of behavioral tests and by video-EEG monitoring.

\section{Materials and Methods}

hAPPJ20 transgenic and Prnp knock-out mice

Hemizygous transgenic and NTG mice were from line J20, which expresses an alternatively spliced hAPPJ20 minigene encoding hAPP695, 
hAPP751, and hAPP770 with the Swedish and Indiana familial AD mutations directed by the PDGF $\beta$-chain promoter (Rockenstein et al., 1995; Mucke et al., 2000). PrP ${ }^{\mathrm{c}}$-deficient Prnp knock-out mice (B6.129S7-Prnp ${ }^{\text {tm1Cwe }} /$ Orl) were acquired from the European Mutant Mouse Archive. hAPP mice and Prnp ${ }^{-1-}$ mice were on a C57BL/6J background. Mice had access to food (Picolab Rodent Diet 20, Labdiet) and water ad libitum. For all experiments, groups were sex-balanced.

\section{hAPP, C99, and $A \beta$ measurements}

For hAPP and C99 measurements, snap-frozen hippocampal samples were homogenized in PBS containing 0.5 mM EDTA, 1 mM DTT, 0.5\% Triton, 0.1 M PMSF, Phosphatase Inhibitor Cocktails I and II (Sigma-Aldrich), and protease inhibitors (Roche). For $\mathrm{A} \beta$ measurements, the same lysates were diluted 1:2 with $7.5 \mathrm{~m}$ guanidine buffer. Total hAPP and C99 levels in hippocampal samples were assessed by Western blotting. The following antibodies were used: anti-hAPP (8E5, 1:1000; kindly provided by Elan Pharmaceuticals), anti-CTF (CT-15, 1:1000; kindly provided by Dr. Eddy Koo, University of California at San Diego, La Jolla, CA), and anti-tubulin (Sigma). $\mathrm{A} \beta_{1-x}$ and $\mathrm{A} \beta_{1-42}$ levels were quantified by ELISA as described previously (Johnson-Wood et al., 1997; Mucke et al., 2000) and expressed relative to total protein concentration determined by Bradford assay.

\section{Behavioral tests}

Elevated plus maze. The elevated plus maze has two open (without walls) and two enclosed (with walls) arms elevated $63 \mathrm{~cm}$ above the ground (Hamilton-Kinder). Mice were acclimated to the testing room under dim light for $1 \mathrm{~h}$ and tested as described previously (Harris et al., 2010; Cissé et al., 2011).

Open field. Spontaneous locomotor activity in an open field was measured as described previously (Harris et al., 2010; Cissé et al., 2011).

Novel object recognition. Mice were acclimated in the testing room for at least $1 \mathrm{~h}$ before testing. Testing was performed as described previously (Harris et al., 2010; Cissé et al., 2011) and the frequency of object interactions and time spent exploring each object were recorded with a video tracking system (Noldus) for analysis.

Morris water maze. The apparatus and training protocol have been described previously (Harris et al., 2010; Cissé et al., 2011).

\section{EEG recordings}

Mice were implanted for video-EEG monitoring after anesthesia with Avertin (tribromoethanol, $250 \mathrm{mg} / \mathrm{kg}$, i.p.). Teflon-coated silver wire electrodes $(0.125 \mathrm{~mm}$ diameter $)$ soldered to a multichannel electrical connector were implanted into the subdural space over the left frontal cortex (coordinates relative to the bregma were $\mathrm{M} / \mathrm{L}, \pm 1 \mathrm{~mm} ; \mathrm{A} / \mathrm{P}, \pm 1$ $\mathrm{mm})$ and the left and right parietal cortex $(\mathrm{M} / \mathrm{L}, \pm 2 \mathrm{~mm}, \mathrm{~A} / \mathrm{P}, \pm 2 \mathrm{~mm})$. The left frontal cortex electrode was a reference. EEG recordings were performed at least $7 \mathrm{~d}$ after surgery on freely moving mice in a recording chamber. EEG activity was recorded with the Harmonie software (version 5.0b) for $48 \mathrm{~h}$. Epileptic spikes were automatically detected by Gotman spike and seizure detectors (Harmonie) and confirmed by inspection of EEG recordings.

\section{Statistical analyses}

Statistical analyses were performed with GraphPad Prism. Differences between two means were assessed by paired or unpaired $t$ test. Differences among multiple means were assessed, as indicated, by one-way, two-way, or repeated-measures ANOVA, followed by Bonferroni's or Tukey's post hoc test. Error bars represent SEM. Differences between observed and expected values were assessed by one- or two-sided $\chi^{2}$ test. Null hypotheses were rejected at the 0.05 level.

\section{Results \\ $\operatorname{PrP}^{\mathrm{c}}$ ablation does not prevent behavioral abnormalities in hAPPJ20 mice}

Like other hAPP transgenic models, hAPPJ20 mice display a disinhibition-like phenotype in the elevated plus maze and hyperactivity in arenas, such as the open field (Chin et al., 2005; Kobayashi and Chen, 2005; Cheng et al., 2007; Roberson et al., 2007; Meilandt et al., 2009; Harris et al., 2010; Cissé et al., 2011).
To determine whether $\operatorname{PrP}^{\mathrm{c}}$ ablation prevents behavioral abnormalities, we generated hAPPJ20 mice with $\left(\operatorname{Prnp}^{+/+}\right)$or without $\left(P r n p^{-1-}\right) \operatorname{PrP}^{c}$ and compared them in these paradigms at 6-8 months, when behavioral abnormalities are readily detectable in hAPPJ20 mice on the Prnp ${ }^{+/+}$background. hAPP/Prnp ${ }^{+/+}$and hAPP/Prnp ${ }^{-1-}$ mice spent more time in the open arms of the elevated plus maze than $\operatorname{Prnp} p^{+/+}$and $\operatorname{Prn} p^{-1-}$ mice without hAPP (Fig. 1A), suggesting disinhibition or lower levels of anxiety. Ablation of $\operatorname{PrP}^{\mathrm{C}}$ had no effect. It also had no significant effect on the hyperactivity of hAPP mice in the open field ( $p=0.132$ by unpaired, one-tailed Student's $t$ test) (Fig. $1 B$ ).

\section{$\operatorname{PrP}^{c}$ ablation does not prevent learning and memory deficits in hAPPJ20 mice}

Like other hAPP transgenic mice, hAPPJ20 mice show deficits in spatial and nonspatial learning and memory (Cheng et al., 2007; Roberson et al., 2007, 2011; Meilandt et al., 2009; Harris et al., 2010; Cissé et al., 2011). Nonspatial learning and memory were assessed in the novel object recognition test. Unlike mice without hAPP, hAPP/Prnp ${ }^{+/+}$and hAPP/Prnp ${ }^{-/-}$mice did not prefer the novel over the familiar object (Fig. $1 C$ ), suggesting deficits in recognizing or remembering the familiar object. Ablation of $\mathrm{PrP}^{\mathrm{c}}$ provided no benefit to hAPP mice.

Spatial learning and memory were tested in the Morris water maze. $\operatorname{PrP}^{c}$ ablation failed to prevent deficits hAPPJ20 mice typically show in this test and even tended to worsen them. In the cued-platform task, all mice learned similarly (data not shown). In the hidden-platform (spatial) version, both hAPP/Prnp ${ }^{+/+}$ and hAPP/Prnp ${ }^{-1-}$ mice showed significant learning deficits compared with $\operatorname{Prnp}^{+/+}$and Prnp ${ }^{-/-}$mice lacking hAPP (Fig. $2 A)$. hAPP mice without $\operatorname{PrP}^{c}$ performed slightly worse than hAPP mice with $\operatorname{PrP}^{c}(p<0.05$ by linear contrast and Bonferroni test). Swim speeds during the hidden platform training were comparable among all groups (data not shown).

At $24 \mathrm{~h}$ after the last training, spatial memory retention was assessed in a probe trial. The platform was removed, and mice were given 60 s to explore the pool. Unlike mice without hAPP, hAPP/Prnp ${ }^{+/+}$and hAPP/Prnp ${ }^{-/-}$mice failed to spend significantly more time in the target quadrant (i.e., where the platform was) than in the other quadrants (Fig. 2 B). hAPP/Prnp ${ }^{+/+}$and hAPP/Prnp ${ }^{-1-}$ mice also failed to cross the original platform location significantly more often than corresponding locations in nontarget quadrants (Fig. 2C). Finally, hAPP/Prnp ${ }^{+/+}$and hAPP/Prnp ${ }^{-1-}$ mice took longer to reach the original platform location than mice without hAPP (Fig. 2D). In all three outcome measures, hAPP/Prnp ${ }^{-1-}$ mice tended to perform worse than hAPP/Prnp ${ }^{+/+}$mice, although these differences did not reach statistical significance.

\section{$\operatorname{PrP}^{c}$ ablation does not change hippocampal levels of hAPP or $\mathrm{A} \boldsymbol{\beta}$ in hAPPJ20 mice}

We compared hippocampal A $\beta$ levels by ELISA and hippocampal levels of hAPP and hAPP C-terminal fragment C99 by Western blots in 8- to 13-month-old hAPP/Prnp ${ }^{+1+}$ and hAPP/Prnp ${ }^{-1-}$ mice ( $n=11-13$ per genotype, mean \pm SEM, relative levels): $\mathrm{A} \beta_{1-x}(148 \pm 23$ vs $100 \pm 26), \mathrm{A} \beta_{1-42}(108 \pm 16$ vs $78 \pm 19)$, $\mathrm{A} \beta_{1-42} / \mathrm{A} \beta_{1-x}$ ratio $(0.67 \pm 0.08$ vs $0.81 \pm 0.05), \mathrm{hAPP}(4895 \pm$ 498 vs $5007 \pm 488)$, and C99 (8310 \pm 1171 vs $6212 \pm 989)$. None of these differences was statistically significant by unpaired $t$ test.

$\operatorname{PrP}^{\mathrm{c}}$ ablation worsens premature mortality in hAPPJ20 mice Like other hAPP transgenic lines, hAPPJ20 mice exhibit early mortality, which may be caused by epileptic seizures (Chin et al., 

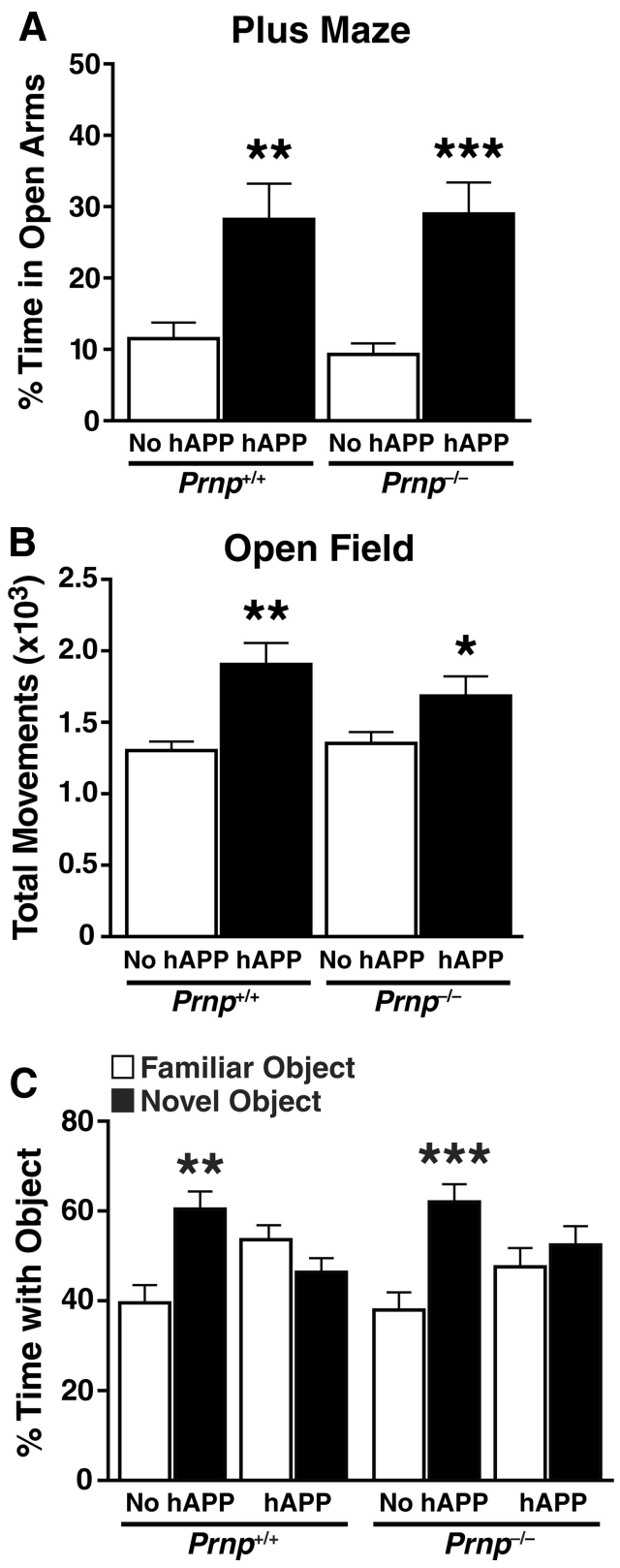

Figure 1. Ablation of $\operatorname{PrP}^{c}$ in hAPPJ20 mice does not prevent their behavioral abnormalities in the elevated plus maze, open field, and object recognition test. $\boldsymbol{A}-\boldsymbol{C}$, Six- to eight-month-old Prnp ${ }^{+/+}$and Prnp ${ }^{-1-}$ mice with or without hAPP ( $n=10-15$ mice per genotype) were tested in the indicated behavioral paradigms. $\boldsymbol{A}$, In the elevated plus maze, mice with hAPP spent more time in the open arms than mice without hAPP. hAPP/ Prnp $^{+/+}$mice and hAPP/Prnp ${ }^{-1-}$ mice showed a similar level of disinhibition. Two-way ANOVA revealed a significant effect of hAPP ( $p<0.0001)$, but not of Prnp ( $p=0.748)$, and no interaction between hAPP and Prnp ( $p=0.607)$. $\boldsymbol{B}$, In the open field, mice with hAPP were hyperactive compared to mice without hAPP. The subtle difference between hAPP/Prnp ${ }^{+/+}$mice and hAPP/Prnp ${ }^{-1-}$ mice was not significant even by one-tailed $t$ test ( $p=0.132)$. Two-way ANOVA revealed a significant effect of hAPP $(p<0.0001)$, but not of Prnp ( $p=0.445)$, and no interaction between hAPP and Prnp ( $p=0.223)$. C, Mice were analyzed in the novel object recognition test. Unlike littermates without hAPP, hAPPJ20/Prnp ${ }^{+/+}$mice and hAPPJ20/Prnp ${ }^{-1-}$ mice failed to spend more time with the novel than with the familiar object in test sessions. Two-way ANOVA of the average ratios of time spent with the novel versus the familiar object revealed a significant effect of hAPP $(p<0.005)$, but not of Prnp $(p=0.322)$, and no interaction between hAPP and Prnp $(p=0.561) .{ }^{*} p<0.05,{ }^{* *} p<0.005,{ }^{* * *} p<0.0005$ versus mice without hAPP of the same Prnp genotype (Tukey test) $(\boldsymbol{A}, \boldsymbol{B})$ or versus familiar object (paired, two-tailed $t$ test) (C). Data represent means \pm SEM.
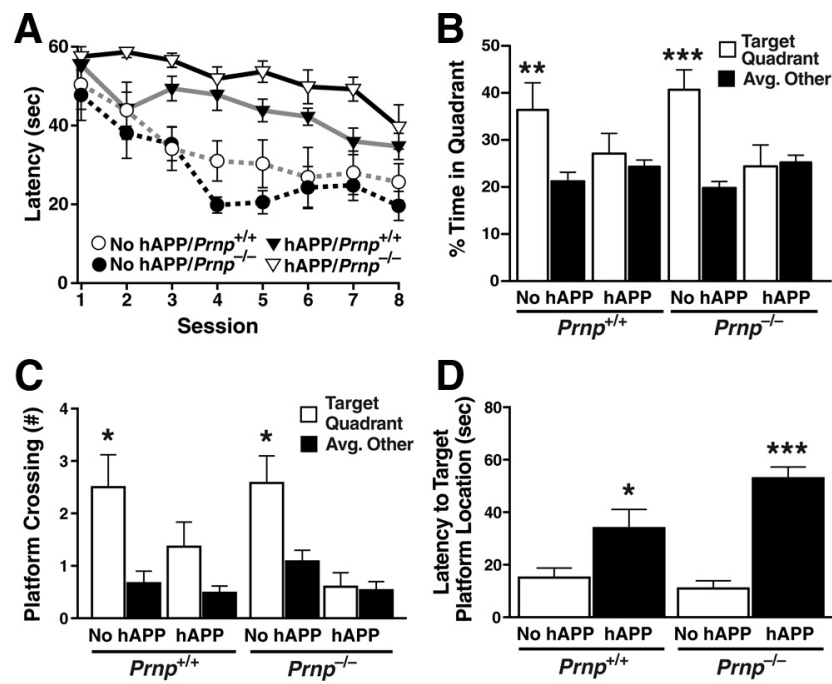

Figure 2. $\operatorname{PrP}^{c}$ ablation in hAPPJ20 mice does not prevent deficits in spatial learning and memory. Six- to eight-month-old Prnp ${ }^{+/+}$and Prnp ${ }^{-/-}$mice with or without hAPP $(n=$ 10-15 mice per genotype) were trained in the Morris water maze for $4 \mathrm{~d}$. Time (latency) and distance swum (data not shown) before reaching the platform were recorded. A probe trial (platform removed) was conducted $24 \mathrm{~h}$ after the last training. A, hAPP/Prnp ${ }^{+/+}$and hAPP/ Prnp ${ }^{-1-}$ mice learned this task more poorly than mice without hAPP. Two-way repeatedmeasures ANOVA revealed a significant effect of hAPP $(p<0.0001)$, but not of Prnp ( $p=$ 0.0613), and no interaction between hAPP and $\operatorname{Prnp}(p=0.632) . B, C$, During the probe trial, mice without hAPP, but not mice with hAPP, favored the target quadrant $(\boldsymbol{B})$ and crossed the target location more often than corresponding places in nontarget quadrants (C). Two-way ANOVA of these data revealed a significant effect of hAPP $(B, p<0.05 ; C, p<0.005)$, but not of Prnp ( $\boldsymbol{B}, p=0.8691 ; \boldsymbol{C}, p=0.647)$, and no interaction between hAPP and Prnp ( $\boldsymbol{B}, p=$ $0.4620 ; C, p=0.281)$. $\boldsymbol{D}$, During the probe trial, mice with hAPP took longer to reach the target location than mice without hAPP. Two-way ANOVA revealed a significant effect of hAPP ( $p<$ $0.0001)$, but not of Prnp ( $p=0.238)$, and no interaction between hAPP and Prnp ( $p=0.483$ ). One-way ANOVA and Bonferroni test revealed a significant difference between hAPP/Prnp ${ }^{+/+}$ and hAPP/Prnp ${ }^{-1-}$ mice $(p<0.05) .{ }^{*} p<0.05,{ }^{* *} p<0.005,{ }^{* * *} p<0.0005$ versus nontarget quadrants by paired, two-way $t$ test $(\boldsymbol{B}, \boldsymbol{C})$ or versus mice without hAPP of the same Prnp genotype by Tukey test $(\boldsymbol{D})$. Data represent means \pm SEM.

2004; Palop et al., 2007; Roberson et al., 2007, 2011; Meilandt et al., 2009). Prnp ${ }^{+1+}, \operatorname{Prnp}^{-1-}$, hAPP/Prnp ${ }^{+/+}$and hAPP/ Prnp ${ }^{-1-}$ mice were born at comparable proportions (Fig. $3 A$ ). However, from birth to weaning (P27), more hAPP mice tended to die than mice without hAPP, independently of Prnp genotype (Fig. 3B). By 8 months of age, $8 \%$ of hAPP/Prnp ${ }^{+/+}$mice died (Fig. 3C). Surprisingly, $\operatorname{PrP}^{\mathrm{c}}$ ablation worsened early mortality in hAPPJ 20 mice, resulting in a $22 \%$ death rate in hAPP/Prnp ${ }^{-1-}$ mice (Fig. $3 C$ ). During the observation period, only one death occurred in Prnp ${ }^{+1+}$ or Prnp ${ }^{-1-}$ mice lacking hAPP.

$\operatorname{PrP}^{\mathrm{c}}$ ablation does not prevent spontaneous epileptiform activity in hAPPJ20 mice

EEG recordings from the neocortex and hippocampus of hAPPJ20 mice revealed spontaneous epileptiform activity (Palop et al., 2007), and similar findings have been obtained in other lines of hAPP mice (Minkeviciene et al., 2009; Roberson et al., 2011). Because Prnp ${ }^{-1-}$ mice were reported as more resistant to proconvulsant drugs than Prnp $^{+/+}$mice (Ratté et al., 2011), we examined whether $\operatorname{PrP}^{\mathrm{c}}$ ablation makes hAPPJ20 mice more resistant to A $\beta$-induced epileptiform activity. $\operatorname{Prnp}^{+/+}$and Prnp ${ }^{-1-}$ mice with or without hAPP were compared by $48 \mathrm{~h}$ video and EEG recordings at $6-8$ months of age. Bilateral recording electrodes over the parietal cortex revealed very few or no spikes in mice without hAPP (Fig. $4 A$ ) and an average of 7 spikes per hour in hAPPJ20/Prnp ${ }^{+/+}$mice (Fig. $4 B$ ). Remarkably, PrP ${ }^{c}$ 


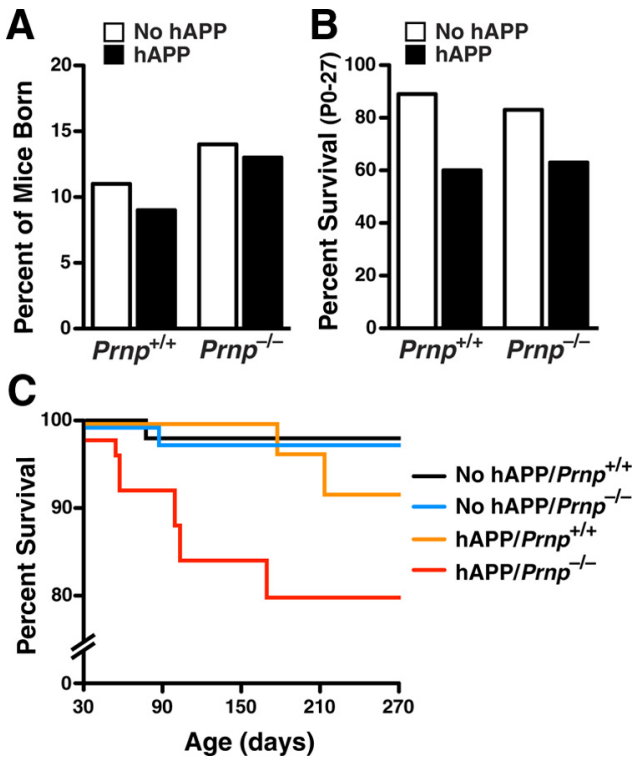

Figure 3. Ablation of PrP ${ }^{\mathrm{C}}$ worsens early mortality in $\mathrm{hAPPJ} 20$ mice. Death and survival were monitored in a total of 169 mice. $\boldsymbol{A}$, Percentage of mice born by genotype. The difference between the number of mice obtained and expected for each genotype, based on Mendelian principles of inheritance (12.5\%), was not significant $\left(\chi^{2}=0.72 ; p=0.86\right)$. $\boldsymbol{B}$, Premature death reported from P0 to P27. Mortality tended to be higher in hAPP than NTG mice (one-sided $\chi^{2}=1.9, p=0.07$ ), independently of their Prnp genotype (two-sided $\chi^{2}=0.28, p=0.59$ ). $C$, Kaplan-Meier survival plot shows more mice with hAPP died prematurely than mice without hAPP after weaning ( $p<0.01$, Mantel-Cox test). Premature mortality was greater in hAPP/ Prnp ${ }^{-1-}$ mice than in hAPP/Prnp ${ }^{+/+}$mice $(p<0.001$, Mantel-Cox test).

ablation actually doubled the epileptiform activity recorded in hAPPJ 20 mice (Fig. 4 B). No seizures occurred during the recording period in any of the groups.

\section{Discussion}

$\mathrm{PrP}^{\mathrm{c}}$ ablation did not prevent neuronal network dysfunction and behavioral abnormalities in hAPPJ20 transgenic mice. In fact, it doubled the early mortality rate and epileptiform activity in this line. The resulting selection process and survival of mice with relative resistance against the synergistic effects of hAPP/A $\beta$ overexpression and $\operatorname{PrP}^{\mathrm{c}}$ ablation might have diminished our ability to detect an exacerbating effect of $\operatorname{PrP}^{c}$ ablation on hAPP/A $\beta$-dependent behavioral abnormalities. Subtle signs of such an effect were evident in the probe trial of the Morris water maze test.

These results differ from studies showing that $\mathrm{PrP}^{\mathrm{c}}$ ablation prevents $\mathrm{A} \beta$-induced LTP deficits in acute hippocampal slices (Laurén et al., 2009) and diminishes early mortality and impairments in spatial learning and memory in APPswe/PSen $\Delta \mathrm{E} 9$ transgenic mice (Gimbel et al., 2010). However, our findings agree with others showing that $\operatorname{PrP}^{\mathrm{c}}$ ablation does not affect $\mathrm{A} \beta$-induced synaptic depression, reduction in spine density, and LTP deficits in acute hippocampal slices (Kessels et al., 2010), behavioral impairments from intracerebroventricular injection of $\mathrm{A} \beta$ (Balducci et al., 2010), and impairments of hippocampal synaptic plasticity (Calella et al., 2010).

hAPPJ20 mice and other hAPP lines show epileptiform activity (Palop and Mucke, 2010; Roberson et al., 2011). Genetic manipulations that prevent or counteract aberrant excitatory neuronal activity (e.g., ablation of Fyn, group IVA phospholipase $\mathrm{A} 2$, or tau) reduce premature mortality and/or cognitive deficits in hAPP-J20 mice (Chin et al., 2004, 2005; Roberson et al., 2007, 2011; Sanchez-Mejia et al., 2008). Interestingly, $\operatorname{PrP}^{\mathrm{c}}$ has also been implicated in epilepsy (Walz et al., 2002). However, $\mathrm{PrP}^{\mathrm{c}}$ ablation actually increased premature mortality and did not affect

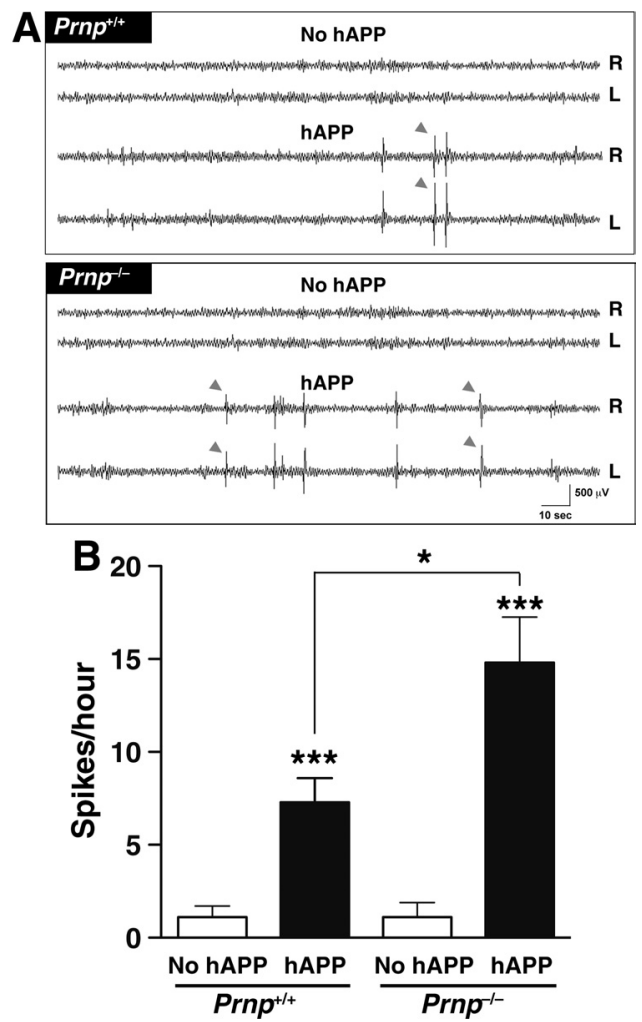

Figure 4. Ablation of $\operatorname{PrP}^{C}$ worsens spontaneous epileptiform activity in hAPPJ20 mice. EEG was recorded over both parietal cortices for $48 \mathrm{~h}$ in 6 - to 8 -month-old mice $(n=3-6$ mice per genotype). $\boldsymbol{A}$, In contrast to mice lacking hAPP, hAPP/Prnp ${ }^{+/+}$and hAPP/Prnp ${ }^{-/-}$mice showed frequent epileptiform spikes (see gray arrowheads). L, Left; $R$, right. $B$, Quantification of epileptiform spikes. Two-way ANOVA revealed effects of hAPP ( $p<0.0001)$ and Prnp ( $p=$ $0.03)$, and an interaction between hAPP and $\operatorname{Prnp}(p=0.036) .{ }^{*} p<0.01,{ }^{* * *} p<0.0001$ versus mice without hAPP or as indicated by bracket (Bonferroni post hoc test). Values are means \pm SEM.

cognitive deficits in hAPPJ20 mice, making it unlikely that it protects against $\mathrm{A} \beta$-induced seizure activity, which is closely linked to cognitive impairments in these mice (Palop et al., 2007; Palop and Mucke, 2010; Roberson et al., 2011). Indeed, $\operatorname{PrP}^{\mathrm{c}}$ ablation enhanced spontaneous epileptiform activity in hAPPJ20 mice, consistent with the increased susceptibility of Prnp ${ }^{-1-}$ mice to kainate-induced seizures (Walz et al., 1999; Rangel et al., 2007).

We found that $\operatorname{PrP}^{\mathrm{c}}$ ablation doubled premature mortality in hAPPJ20 mice but had no effect on mice without hAPP, suggesting a specific interaction between hAPP/A $\beta$ - and $\mathrm{PrP}^{\mathrm{c}}$-dependent mechanisms. The lower seizure threshold of $P r n p^{-/-}$mice might partially explain the increased early mortality of hAPPJ20/Prnp ${ }^{-l-}$ mice. These results are in stark contrast to the increased survival of $\operatorname{PrP}^{\mathrm{c}}$ deficient APPswe/PSen $\Delta \mathrm{E} 9$ mice, which were also on the C57BL/6J background (Gimbel et al., 2010).

The different effects of $\operatorname{PrP}^{c}$ ablation on $\mathrm{A} \beta$-induced deficits observed by different investigators might stem from differences in experimental protocols, hAPP lines and Prnp ${ }^{-1-}$ strains. For example, if levels of pathogenic $A \beta$ oligomers in relevant brain regions were higher in hAPPJ20 mice than in APPswe/PSen $\Delta \mathrm{E} 9$ mice, beneficial effects of $\operatorname{PrP}^{c}$ ablation in hAPPJ20 mice might have been obscured. However, if $\operatorname{PrP}^{\mathrm{c}}$ were crucial in $\mathrm{A} \beta$ induced cognitive deficits, its ablation should prevent those deficits in hAPPJ20 mice as did ablation of group IVA phospholipase $\mathrm{A}_{2}$ (Sanchez-Mejia et al., 2008) or tau (Roberson et al., 2007, 2011). Even partial reduction of these two molecules in hemizygous knock-out mice significantly ameliorated the deficits in 
hAPPJ20 mice (Roberson et al., 2007, 2011; Sanchez-Mejia et al., 2008). Thus, $A \beta$-induced cognitive deficits in hAPPJ 20 mice are not so severe that they simply cannot be overcome by any intervention. In fact, neuronal and cognitive dysfunction in these mice could be reversed effectively by normalizing neuronal expression of EphB2, an alternative receptor for $A \beta$ oligomers (Cissé et al., 2011).

Because $\mathrm{A} \beta$ binds to many molecules (Dineley et al., 2002; Laurén et al., 2009; Origlia et al., 2009; Balducci et al., 2010; Renner et al., 2010; Cissé et al., 2011), it is critical to determine which of these interactions have the greatest functional impact. Interactions of $\mathrm{A} \beta$ oligomers with the receptor for advanced glycation end products (Origlia et al., 2009) and with EphB2 (Cissé et al., 2011) have striking effects on neuronal and cognitive functions and, we suspect, may be more promising targets for therapeutic interventions in $\mathrm{AD}$ than $\operatorname{PrP}^{\mathrm{c}}$.

\section{References}

Aguzzi A, Baumann F, Bremer J (2008) The prion's elusive reason for being. Annu Rev Neurosci 31:439-477.

Ashe KH, Zahs KR (2010) Probing the biology of Alzheimer's disease in mice. Neuron 66:631-645.

Balducci C, Beeg M, Stravalaci M, Bastone A, Sclip A, Biasini E, Tapella L, Colombo L, Manzoni C, Borsello T, Chiesa R, Gobbi M, Salmona M, Forloni G (2010) Synthetic amyloid-\{beta\} oligomers impair long-term memory independently of cellular prion protein. Proc Natl Acad Sci U S A 107:2295-2300.

Büeler H, Fischer M, Lang Y, Bluethmann H, Lipp H, DeArmond S, Prusiner S, Aguet M, Weissmann C (1992) Normal development and behaviour of mice lacking the neuronal cell-surface PrP protein. Nature 356:577-582.

Calella AM, Farinelli M, Nuvolone M, Mirante O, Moos R, Falsig J, Mansuy IM, Aguzzi A (2010) Prion protein and Abeta-related synaptic toxicity impairment. EMBO Mol Med 2:306-314.

Cheng IH, Scearce-Levie K, Legleiter J, Palop JJ, Gerstein H, Bien-Ly N, Puoliväli J, Lesné S, Ashe KH, Muchowski PJ, Mucke L (2007) Accelerating amyloid- $\beta$ fibrillization reduces oligomer levels and functional deficits in Alzheimer disease mouse models. J Biol Chem 282:23818-23828.

Chin J, Palop JJ, Yu G-Q, Kojima N, Masliah E, Mucke L (2004) Fyn kinase modulates synaptotoxicity, but not aberrant sprouting, in human amyloid precursor protein transgenic mice. J Neurosci 24:4692-4697.

Chin J, Palop JJ, Puoliväli J, Massaro C, Bien-Ly N, Gerstein H, Scearce-Levie K, Masliah E, Mucke L (2005) Fyn kinase induces synaptic and cognitive impairments in a transgenic mouse model of Alzheimer's disease. J Neurosci 25:9694-9703.

Cissé M, Halabisky B, Harris J, Devidze N, Dubal DB, Sun B, Orr A, Lotz G, Kim DH, Hamto P, Ho K, Yu G-Q, Mucke L (2011) Reversing EphB2 depletion rescues cognitive functions in Alzheimer model. Nature 469:47-52.

Dineley KT, Bell KA, Bui D, Sweatt JD (2002) b-Amyloid peptide activates a7 nicotinic acetylcholine receptors expressed in Xenopus oocytes. J Biol Chem 277:25056-25061.

Gimbel DA, Nygaard HB, Coffey EE, Gunther EC, Laurén J, Gimbel ZA, Strittmatter SM (2010) Memory impairment in transgenic Alzheimer mice requires cellular prion protein. J Neurosci 30:6367-6374.

Harris JA, Devidze N, Halabisky B, Lo I, Thwin MT, Yu GQ, Bredesen DE, Masliah E, Mucke L (2010) Many neuronal and behavioral impairments in transgenic mouse models of Alzheimer's disease are independent of caspase cleavage of the amyloid precursor protein. J Neurosci 30:372-381.

Johnson-Wood K, Lee M, Motter R, Hu K, Gordon G, Barbour R, Khan K, Gordon M, Tan H, Games D, Lieberburg I, Schenk D, Seubert P, McConlogue L (1997) Amyloid precursor protein processing and $\mathrm{A} \beta_{42}$ deposition in a transgenic mouse model of Alzheimer disease. Proc Natl Acad Sci U S A 94:1550-1555.

Kessels HW, Nguyen LN, Nabavi S, Malinow R (2010) The prion protein as a receptor for amyloid-beta. Nature 466:E3-E4; discussion E4-E5.

Kobayashi DT, Chen KS (2005) Behavioral phenotypes of amyloid-based genetically modified mouse models of Alzheimer's disease. Genes Brain Behav 4:173-196.

Laurén J, Gimbel DA, Nygaard HB, Gilbert JW, Strittmatter SM (2009) Cellular prion protein mediates impairment of synaptic plasticity by amyloid-beta oligomers. Nature 457:1128-1132.
Meilandt WJ, Yu G-Q, Chin J, Roberson ED, Palop JJ, Wu T, Scearce-Levie K, Mucke L (2008) Enkephalin elevations contribute to neuronal and behavioral impairments in a transgenic mouse model of Alzheimer's disease. J Neurosci 28:5007-5017.

Meilandt WJ, Cisse M, Ho K, Wu T, Esposito LA, Scearce-Levie K, Cheng IH, Yu GQ, Mucke L (2009) Neprilysin overexpression inhibits plaque formation but fails to reduce pathogenic $A \beta$ oligomers and associated cognitive deficits in human amyloid precursor protein transgenic mice. J Neurosci 29:1977-1986.

Minkeviciene R, Rheims S, Dobszay MB, Zilberter M, Hartikainen J, Fülöp L, Penke B, Zilberter Y, Harkany T, Pitkänen A, Tanila H (2009) Amyloid beta-induced neuronal hyperexcitability triggers progressive epilepsy. J Neurosci 29:3453-3462.

Mucke L, Masliah E, Yu G-Q, Mallory M, Rockenstein EM, Tatsuno G, Hu K, Kholodenko D, Johnson-Wood K, McConlogue L (2000) High-level neuronal expression of $\mathrm{A} \beta_{1-42}$ in wild-type human amyloid protein precursor transgenic mice: synaptotoxicity without plaque formation. J Neurosci 20:4050-4058.

Origlia N, Arancio O, Domenici L, Yan SS (2009) MAPK, beta-amyloid and synaptic dysfunction: the role of RAGE. Expert Rev Neurother 9: $1635-1645$.

Palop JJ, Mucke L (2010) Amyloid-beta-induced neuronal dysfunction in Alzheimer's disease: from synapses toward neural networks. Nat Neurosci 13:812-818.

Palop JJ, Chin J, Roberson ED, Wang J, Thwin MT, Bien-Ly N, Yoo J, Ho KO, Yu G-Q, Kreitzer A, Finkbeiner S, Noebels JL, Mucke L (2007) Aberrant excitatory neuronal activity and compensatory remodeling of inhibitory hippocampal circuits in mouse models of Alzheimer's disease. Neuron 55:697-711.

Rangel A, Burgaya F, Gavín R, Soriano E, Aguzzi A, Del Río JA (2007) Enhanced susceptibility of Prnp-deficient mice to kainate-induced seizures, neuronal apoptosis, and death: role of AMPA/kainate receptors. J Neurosci Res 85:2741-2755.

Ratté S, Vreugdenhil M, Boult JK, Patel A, Asante EA, Collinge J, Jefferys JG (2011) Threshold for epileptiform activity is elevated in prion knockout mice. Neuroscience 179:56-61.

Renner M, Lacor PN, Velasco PT, Xu J, Contractor A, Klein WL, Triller A (2010) Deleterious effects of amyloid beta oligomers acting as an extracellular scaffold for mGluR5. Neuron 66:739-754.

Roberson ED, Scearce-Levie K, Palop JJ, Yan F, Cheng IH, Wu T, Gerstein H, Yu G-Q, Mucke L (2007) Reducing endogenous tau ameliorates amyloid $\beta$-induced deficits in an Alzheimer's disease mouse model. Science 316:750-754.

Roberson ED, Halabisky B, Yoo JW, Yao J, Chin J, Yan F, Wu T, Hamto P, Devidze N, Yu G-Q, Palop JJ, Noebels JL, Mucke L (2011) Amyloid- $\beta$ / Fyn-induced synaptic, network, and cognitive impairments depend on Tau levels in multiple mouse models of Alzheimer's disease. J Neurosci 31:700-711.

Rockenstein EM, McConlogue L, Tan H, Power M, Masliah E, Mucke L (1995) Levels and alternative splicing of amyloid b protein precursor (APP) transcripts in brains of transgenic mice and humans with Alzheimer's disease. J Biol Chem 270:28257-28267.

Sakono M, Zako T (2010) Amyloid oligomers: formation and toxicity of Abeta oligomers. FEBS J 277:1348-1358.

Sanchez-Mejia RO, Newman JW, Toh S, Yu G-Q, Zhou Y, Halabisky B, Cissé M, Scearce-Levie K, Cheng IH, Gan L, Palop JJ, Bonventre JV, Mucke L (2008) Phospholipase A2 reduction ameliorates cognitive deficits in mouse model of Alzheimer's disease. Nat Neurosci 11:1311-1318.

Shankar GM, Li S, Mehta TH, Garcia-Munoz A, Shepardson NE, Smith I, Brett FM, Farrell MA, Rowan MJ, Lemere CA, Regan CM, Walsh DM, Sabatini BL, Selkoe DJ (2008) Amyloid-beta protein dimers isolated directly from Alzheimer's brains impair synaptic plasticity and memory. Nat Med 14:837-842.

Thies W, Bleiler L (2011) 2011 Alzheimer's disease facts and figures. Alzheimers Dement 7:208-244.

Walz R, Amaral OB, Rockenbach IC, Roesler R, Izquierdo I, Cavalheiro EA, Martins VR, Brentani RR (1999) Increased sensitivity to seizures in mice lacking cellular prion protein. Epilepsia 40:1679-1682.

Walz R, Castro RM, Velasco TR, Carlotti CG Jr, Sakamoto AC, Brentani RR, Martins VR (2002) Cellular prion protein: implications in seizures and epilepsy. Cell Mol Neurobiol 22:249-257. 